\title{
SERUM BIOMARKERS IN PATIENTS WITH STABLE AND ACUTE EXACERBATION OF CHRONIC OBSTRUCTIVE PULMONARY DISEASE: A COMPARATIVE STUDY
}

\author{
SERUMSKI BIOMARKERI KOD PACIJENATA SA STABILNIM I AKUTNIM POGORŠANJEM \\ HRONIČNE OPSTRUKTIVNE PLUĆNE BOLESTI: KOMPARATIVNA STUDIJA
}

\author{
Füsun Şahin, Ayşe Filiz Koşar, Ayşe Feyza Aslan, Burcu Yiğitbaş, Berat Uslu \\ Department of Chest Diseases, University of Health Sciences/Yedikule Chest Disease \\ and Thoracic Surgery Health Practice and Research Center, Istanbul, Turkey
}

\begin{abstract}
Summary
Background: Mean platelet volume (MPV), neutrophil-tolymphocyte ratio (NLR) and platelet-to-lymphocyte ratio (PLR) have all been investigated as novel inflammatory markers of cardiac and oncological diseases, while there is only a limited number of studies investigating these markers in chronic obstructive pulmonary disease (COPD). In the present study we examine NLR, PLR; and other markers, such as eosinophil, MPV, plateletcrit (PCT), platelet distribution width (PDW), red cell distribution width (RDW), and $\mathrm{C}$-reactive protein (CRP) in patients with stable and acute exacerbation of COPD.

Methods: Stable COPD (Group 1, $\mathrm{n}=140$ ), COPD with acute exacerbation (Group 2, n=110), and healthy controls (Group 3, n=50) were included in the study. Leukocyte, CRP, hemoglobin (HB), RDW, platelet, MPV, PCT, PDW, neutrophil, lymphocyte, eosinophil, NLR, and PLR were analyzed in all groups.

Results: HB, leukocyte, platelet, neutrophil, eosinophil, MPV, PCT, CRP, NLR, and PLR were significantly higher, while the lymphocyte was lower in Group 1 than in Group 3. Leukocyte, neutrophil, RDW, CRP, NLR, and PLR were significantly higher, while lymphocyte was lower in Group 2 than in Group 3. Leukocyte, neutrophil, RDW, CRP, NLR, and PLR were significantly higher, while HB, platelet, MPV, $P C T$, and lymphocyte were significantly lower in Group 2 than in Group 1. NLR and PLR increased significantly in patients with bronchiectasis when compared to those without in Group 1.
\end{abstract}

\begin{abstract}
Kratak sadržaj
Uvod: Srednji nivo trombocita (MPV), odnos neutrofila i limfocita (NLR) i odnos trombocita i limfocita (PLR) su istraženi kao novi zapaljenski markeri srčanih i onkoloških bolesti. Međutim, postoji ograničen broj studija koje istražuju ove markere u hroničnoj opstruktivnoj bolesti pluća (HOBP). Cilj je bio da se ispitaju NLR, PLR i drugi markeri kao što su eozinofili, MPV, trombociti (PCT), širina širenja trombocita (PDW), širina distribucije eritrocita (RDW), Creaktivni protein (CRP) kod pacijenata sa stabilnim i akutnim pogoršanjem HOBP.

Metode: Ispitivani su stabilna HOBP (grupa 1, $n=140$ ), HOBP sa napadom (grupa $2, \mathrm{n}=110$ ), i zdrave kontrole (grupa 3, n = 50). U svim grupama analizirani su leukociti, CRP, hemoglobin (Hb), RDW, trombociti, MPV, PCT, PDW, neutrofili, limfociti, eozinofili, NLR, PLR.

Rezultati: Hb, leukociti, trombociti, neutrofili, eozinofili, MPV, PCT, CRP, NLR, PLR bili su značajno veći, dok su limfociti bili manji u grupi 1 nego u grupi 3. Leukociti, neutrofili, RDW, CRP, NLR, PLR bili su znatno viši, dok su limfociti bili bio niži u grupi 2 nego u grupi 3. Leukociti, neutorfili, RDW, CRP, NLR, PLR bili su znatno viši, dok su $\mathrm{Hb}$, trombociti, MPV, PCT, limfociti bili znatno niži u grupi 2 nego u grupi 1. NLR i PLR bili su značajno povećani kod pacijenata sa bronhiektazom u poređenju sa onima koji nisu u grupi 1.

Zaključak: Naši rezultati istraživanja ukazuju na to da su NLR, PLR i RDW jednostavni i isplativi markeri za procenu
\end{abstract}

Address for correspondence:

Assoc. Prof. Dr. Füsun Şahin

Department of Chest Diseases, University of Health Sciences/Yedikule

Chest Disease and Thoracic Surgery Health Practice and Research

Center Istanbul, Turkey

Telephone: +90 5327112893 Fax: +90 2125472233

e-mail: fusunsahin19700@hotmail.com

ORCID ID: FÜSUN ŞAHIN ORCID ID

https: //orcid.org/0000-0002-8415-2524 
Conclusions: Our study results suggest that NLR, PLR and RDW can be used as simple and cost-effective markers for the evaluation of severity of exacerbation and for predicting hospitalization and further exacerbations in patients with COPD.

Keywords: COPD, neutrophil/lymphocyte ratio, platelet/ lymphocyte ratio, inflammatory biomarkers

\section{Introduction}

Chronic obstructive pulmonary disease (COPD), which is characterized by a chronic inflammatory response of the airways and lungs to noxious gas and particles along with progressive and irreversible airflow limitation, is a preventable and treatable condition (1). Although the underlying mechanism is still unclear, mild systemic inflammation has been blamed, and leukocyte and C-reactive protein (CRP) are used to evaluate inflammation. There is a proven correlation between these markers and airflow limitation and disease severity (forced expiratory volume in one second [FEV1], forced vital capacity [FVC], inspiratory capacity/total lung capacity [IC/TLC], Global Initiative for Chronic Obstructive Lung Disease [GOLD] stages, and Body Mass Index (BMI), and Airflow Obstruction, Dyspnea, and Exercise Capacity [BODE] Index) (2).

Pulmonary inflammation results in the entry of cytokines including tumor necrosis factor-alpha (TNF$\alpha$ ), interleukin (IL)-1, IL-6, and IL-8 into the systemic circulation, leading to such increased acute phase proteins as CRP, fibrinogen, serum amyloid A, and surfactant protein $D(3)$. This increase is more prominent during exacerbations (4). In COPD exacerbations, tracheobronchial infections account for $50-70 \%$ of cases (bacterial causatives $40-50 \%$, viral causatives 30-40\%, and atypical bacterial causatives $5-10 \%)$, while air pollution accounts for $10 \%$ of cases; however, the etiology remains unknown in about $30 \%$ of cases (5). In such cases, the aforementioned markers are useful for identifying and evaluating exacerbation severity. Leukocyte count and CRP, as inflammatory markers in the blood increase during exacerbations, although the use of these markers is limited in the differential diagnosis of infectious and non-infectious exacerbations (6).

In recent years, mean platelet volume (MPV), neutrophil-to-lymphocyte ratio (NLR) and platelet-tolymphocyte ratio (PLR) have been investigated as novel inflammatory markers of cardiac and oncological diseases $(7,8)$. These markers have been shown also to increase significantly in patients with lung cancer and pulmonary embolism $(9,10)$, although there is a limited number of studies investigating these markers in COPD patients with acute exacerbation $(11,12)$. In the present study, we examine the role of inflammatory and biomarkers [such as ozbiljnosti pogoršanja i predviđanja za hospitalizaciju i dalju procenu pogoršanja kod pacijenata sa HOBP.

Ključne reči: HOBP, odnos neutrofila/limfocita, odnos trombocita/limfocita, biomarkeri zapaljenja

leukocyte, eosinophil, CRP, NLR, PLR, MPV, plateletcrit (PCT), platelet distribution width (PDW) and additionally hemoglobin $(\mathrm{Hb})$, and red cell distribution width (RDW)] in patients with stable and acute exacerbation of chronic obstructive pulmonary disease (COPD).

\section{Materials and Methods}

\section{Study Population}

Between January 2016 and December 2017, a total of 140 patients with stable COPD (Group 1), 110 patients with an acute exacerbation of COPD (Group 2), and 50 healthy controls (Group 3) were included in the study. The diagnosis of COPD was based on the GOLD criteria (a compatible history and spirometry, a post bronchodilator FEV1/forced vital capacity ratio of $70 \%$, or less, and an FEV1 and forced vital capacity ratio of $70 \%$, or less) (1). An acute exacerbation of COPD was defined as follows: increased dyspnea and decreased performance in daily activities, altered amount and color of sputum, increased coughing, pyrexia and/or altered mental status (13). Patients with hematological or renal disease, hepatic impairment; those with active bleeding; those with a history of blood transfusion in the preceding 3 months; those experiencing a pulmonary embolism in the last month; those with acute myocardial infarction or cerebrovascular disease; those with a history of myeloproliferative disease; those with an autoimmune disease; and those with any other form of cancer were excluded from the study. Information the data of retrospective patients was obtained from hospital records, and prespective patients' data was also recorded. This prospective and retrospective observational, analytical cohort study was conducted in accordance with the ethical principles for clinical research based on the Declaration of Helsinki. The study was approved by the institutional review board and written informed consent was obtained from all prospective study participants.

\section{Laboratory Measurements}

The leukocyte count, CRP, HB, RDW, platelet (PLT) count, eosinophil, MPV, PCT, PDW, neutrophil and lymphocyte counts, NLR, and PLR were analyzed in all groups. The results of the patient group were 
compared with the healthy controls. Full blood counts were carried out using ABX Pentra 120 (Minnesota, USA); CRP with Olympus AU2700 Plus, Beckman Coulter (Tokyo, Japan) devices in the groups. NLR was calculated by dividing the absolute neutrophil count by the absolute lymphocyte count. PLR was calculated by dividing the absolute PLT count by the absolute lymphocyte count.

\section{Statistical Analysis}

All statistical analyses were performed using the SPSS 16.0 statistical software package (SPSS Inc., Chicago, IL, USA). The measurements of all COPD patients included in the study were compared with the values of in the healthy control group. One-way analysis of variance (ANOVA) and multiple comparisons were used to analyze the differences between the groups (a Scheffe's test for normal variance and a Games-Howell test for abnormal variance). Chi-square and independent group t-tests were used to compare the NLR and PLR values of patients with bronchiectasis and stable and acute exacerbations of COPD. Receiver operating characteristic (ROC) curve analysis was used to calculate the sensitivity and specificity of NLR, PLR, CRP, RDW, MPV and PCT to detecting COPD patients with acute exacerbation. A $p$ value of $<0.05$ was considered statistically significant.

\section{Results}

The platelet, leukocyte, eosinophil and neutrophil counts, HB, MPV, PCT, NLR, PLR, and CRP values were significantly higher, while the lymphocyte count was lower in patients with stable COPD when

Table I Characteristics and laboratory outcomes of the groups.

\begin{tabular}{|c|c|c|c|c|c|c|}
\hline & $\begin{array}{c}\text { Group } 1 \\
(n=110) \\
\text { Mean (SD) }\end{array}$ & $\begin{array}{c}\text { Group } 2 \\
(n=140) \\
\text { Mean (SD) }\end{array}$ & $\begin{array}{c}\text { Group } 3 \\
(n=50) \\
\text { Mean (SD) }\end{array}$ & $\begin{array}{c}\text { Group 1-2 } \\
\text { p value }\end{array}$ & $\begin{array}{c}\text { Group 1-3 } \\
\text { p value }\end{array}$ & $\begin{array}{c}\text { Group 2-3 } \\
\text { p value }\end{array}$ \\
\hline Age & $62.98(10.72)$ & $64.72(9.07)$ & 61.82 (8.99) & 0.38 & 0.73 & 0.29 \\
\hline Sex, F/M & $20 / 90$ & $30 / 110$ & $5 / 45$ & 0.09 & 0.17 & 0.15 \\
\hline$H B, g / d$ & $14.16(1.69)$ & $13.58(2.03)$ & $13.44(0.91)$ & $0.04 *$ & $0.001 *$ & 0.80 \\
\hline RDW, \% & $13.70(1.36)$ & $15.19(2.627)$ & $13.74(1.85)$ & $<0.001^{*}$ & 0.98 & $<0.001^{*}$ \\
\hline WBC, $\mu / L$ & 9237 (2297) & 13559 (9505) & 7100 (1313) & $<0.001^{*}$ & $<0.001^{*}$ & $<0.001^{*}$ \\
\hline Neutrophil, $\mu \mathrm{L}$ & 5908 (1993) & 9922 (4955) & 3595 (768) & $<0.001^{*}$ & $<0.001^{*}$ & $<0.0010$ \\
\hline Lymphocyte, $\mu \mathrm{L}$ & $2425(940)$ & $1734(1338)$ & $2924(811)$ & $<0.001 *$ & $0.01 *$ & $<0.001^{*}$ \\
\hline Eosinophil (\%) & $3.21(3.89)$ & $2.36(2.45)$ & $2.26(1.11)$ & 0.10 & $0.03^{*}$ & 0.97 \\
\hline $\mathrm{PLT}, \times 10^{3} / \mu \mathrm{L}$ & $256920(72749)$ & 240612 (82228) & $232900(37186)$ & 0.23 & $0.01 *$ & 0.69 \\
\hline PDW, \% & $15.99(0.85)$ & 16.59 (9.29) & $14.77(1.95)$ & 0.68 & 0.40 & 0.15 \\
\hline MPV, fL & $9.56(1.37)$ & $8.56(1.07)$ & $8.79(0.70)$ & $<0.001^{*}$ & $<0.001^{*}$ & 0.23 \\
\hline PCT, \% & $0.24(0.06)$ & $0.20(0.07)$ & $0.21(0.04)$ & $<0.001 *$ & $0.01 *$ & 0.34 \\
\hline NLR & $2.79(1.65)$ & $8.51(8.70)$ & $1.31(0.46)$ & $<0.001^{*}$ & $<0.001^{*}$ & $<0.001^{*}$ \\
\hline PLR & $120.98(61.63)$ & 189.99 (138.29) & $84.86(23.97)$ & $<0.001^{*}$ & $<0.001 *$ & $<0.001 *$ \\
\hline CRP, mg/L & $14.97(27.80)$ & 85.33 (86.67) & $2.38(1.95)$ & $<0.001 *$ & $<0.001 *$ & $<0.001 *$ \\
\hline
\end{tabular}

*Significant value $(p<0.05)$. SD, Standard Deviation. COPD, Chronic obstructive pulmonary disease; CRP, C-reactive protein; Group 1, COPD with stable; Group 2, COPD with acute exacerbation; Group 3, Healthy control; F/M, Female/Male; HB, Haemoglobin; MPV, Mean platelet volume; NLR, Neutrophil/lymphocyte ratio; PLT, Platelet; PDW, Platelet distribution width; PCT, Plateletcrit; PLR, Platelet/lymphocyte ratio; RDW, Red cell distribution width; WBC, White blood cell. 
compared to the healthy controls ( $p<0.05$, Table I), while no significant difference in PDW and RDW was noted between the groups ( $p>0.05$, Table I). The leukocyte and neutrophil counts, CRP, RDW, NLR, and PLR values were significantly higher, while the lymphocyte count was lower in patients with acute

Table II NLR and PLR values in the presence and absence of bronchiectasis in COPD patients.

\begin{tabular}{|c|c|c|c|}
\hline \multicolumn{4}{|c|}{ Group 1} \\
\hline & Bronchiectasis & Mean (SD) & $p$ value \\
\hline \multirow[t]{2}{*}{ NLR } & No & $2.66(1.38)$ & $0.009 *$ \\
\hline & Yes $(n=16)$ & $3.8(2.9)$ & \\
\hline \multirow[t]{2}{*}{ PLR } & No & $113.49(49.88)$ & $<0.001 *$ \\
\hline & Yes $(n=16)$ & 178.52 (103.51) & \\
\hline \multicolumn{4}{|c|}{ Group 2} \\
\hline & Bronchiectasis & Mean (SD) & $p$ value \\
\hline \multirow[t]{2}{*}{ NLR } & No & 8.08 (7.96) & 0.449 \\
\hline & Yes $(n=35)$ & 9.44 (10.19) & \\
\hline \multirow[t]{2}{*}{ PLR } & No & 183.93 (128.75) & 0.499 \\
\hline & Yes $(n=35)$ & 203.13 (158.27) & \\
\hline
\end{tabular}

*Significant value $(p<0.05)$. SD, Standard Deviation.

COPD, Chronic obstructive pulmonary disease; Group1, COPD with stable; Group2, COPD with acute exacerbation. NLR, Neutrophil/lymphocyte ratio; PLR, Platelet/lymphocyte ratio. exacerbation of COPD when compared to the healthy controls $(p<0.05$, Table I), while there was no significant difference in the platelet, eosinophil, HB, MPV, PDW, and PCT values between the groups ( $p>0.05$, Table I). The leukocyte and neutrophil counts, CRP, RDW, NLR, and PLR values were significantly higher, while lymphocyte count, platelet, $\mathrm{HB}, \mathrm{MPV}$ and PCT values were significantly lower in patients with acute exacerbation of COPD when compared to the patients with stable COPD $(p<0.05$, Table I). However, there was no significant difference in the eosinophil and PDW values between the groups ( $p>0.05$, Table I). Bronchiectasis was seen in 16 patients in the patients with stable COPD and in 35 patients with acute exacerbation of COPD. The NLR and PLR values were significantly increased in patients with bronchiectasis when compared to those without among the stable COPD patients $(p<0.05$, Table II). Although the NLR and PLR values were higher in patients with bronchiectasis when compared to those without among the patients with acute exacerbation of COPD, the increase did not reach statistical significance ( $p>0.05$, Table II).

ROC curve analysis was performed for the NLR and PLR values to detect COPD patients with an acute exacerbation. The best NLR cut-off value was defined as 2.84, for which the sensitivity was $80 \%$ and the specificity was $74 \%$ (Table III, Figure 1A). The best PLR cut-off value was defined as 112.23, for which the sensitivity was $72 \%$ and the specificity was $63 \%$ (Table III, Figure 1B). The best CRP cut-off value was defined as 11.60, for which the sensitivity was $83 \%$ and the specificity was $82 \%$ (Table III, Figure $2 A)$. The best RDW cut-off value was defined as 13.85, for which the sensitivity was $66 \%$ and the specificity was $65 \%$ (Table III, Figure 2B).

Table III The sensitivity, specificity and cut-off values of NLR, PLR, CRP and RDW in detecting COPD with acute exacerbation.

\begin{tabular}{|c|c|c|c|c|c|c|}
\hline & Value & Sensitivity \% & Specificity \% & AUC & $95 \% \mathrm{Cl}$ & P value \\
\hline NLR & 2.84 & $80^{*}$ & $74^{*}$ & 0.84 & $0.81-0.90$ & $<0.0001^{* *}$ \\
\hline PLR & 112.23 & $72^{*}$ & $63^{*}$ & 0.75 & $0.68-0.80$ & $<0.0001^{* *}$ \\
\hline CRP & 11.60 & $83^{*}$ & $82^{*}$ & 0.89 & $0.84-0.93$ & $<0.0001^{* *}$ \\
\hline RDW & 13.85 & 66 & 65 & 0.69 & $0.62-0.77$ & $<0.0001$ \\
\hline
\end{tabular}

***The best sensitivity and specificity values (cut-off point). **Significant value $(p<0.001)$.

AUC, Area Under the Curve; Cl, Confidence Interval; CRP, C-reactive protein; NLR, neutrophil/lymphocyte ratio; PLR, platelet/lymphocyte ratio; RDW, red cell distribution width. 


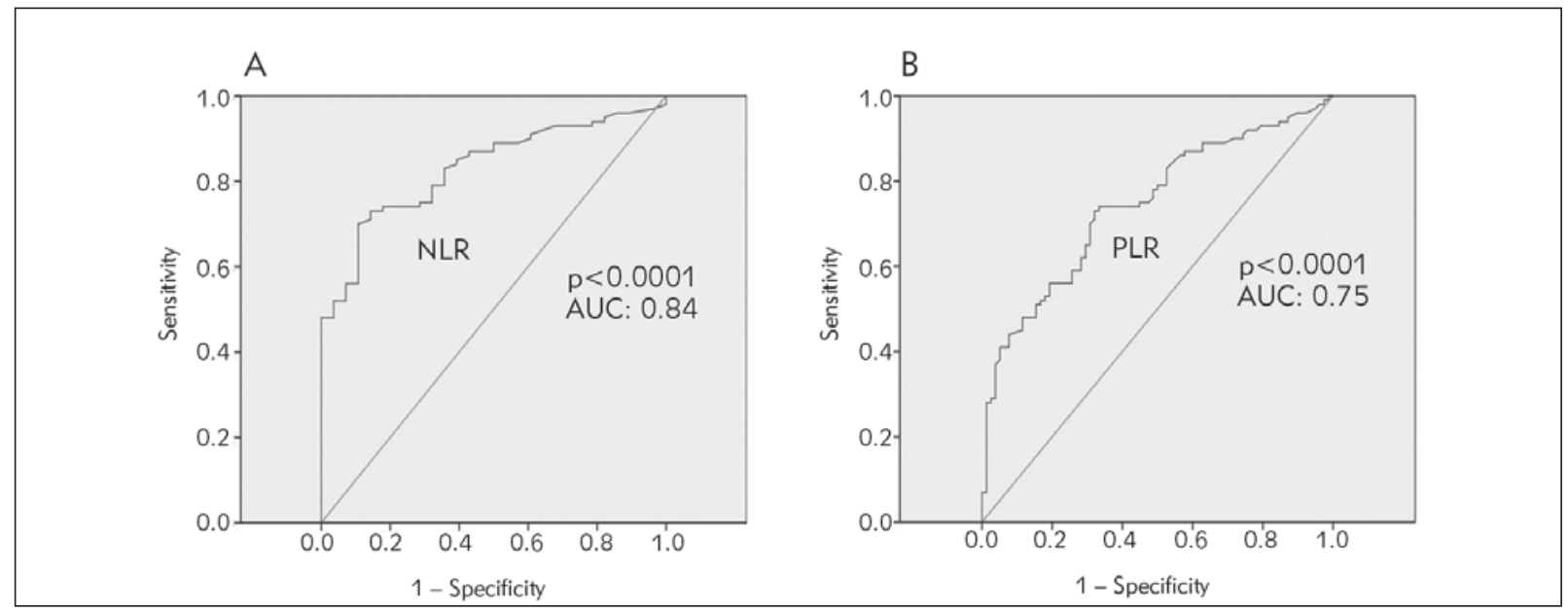

Figure $1 \mathrm{~A}$ ) ROC curve for using NLR (neutrophil/lymphocyte ratio) levels and AUC value (area under the curve) in the differential diagnosis of Group 1 (COPD patients with stable) and Group 2 (COPD patients with exacerbation). B) ROC curve for using PLR (platelet/lymphocyte ratio) levels and AUC value in the differential diagnosis of Group 1 and Group 2.
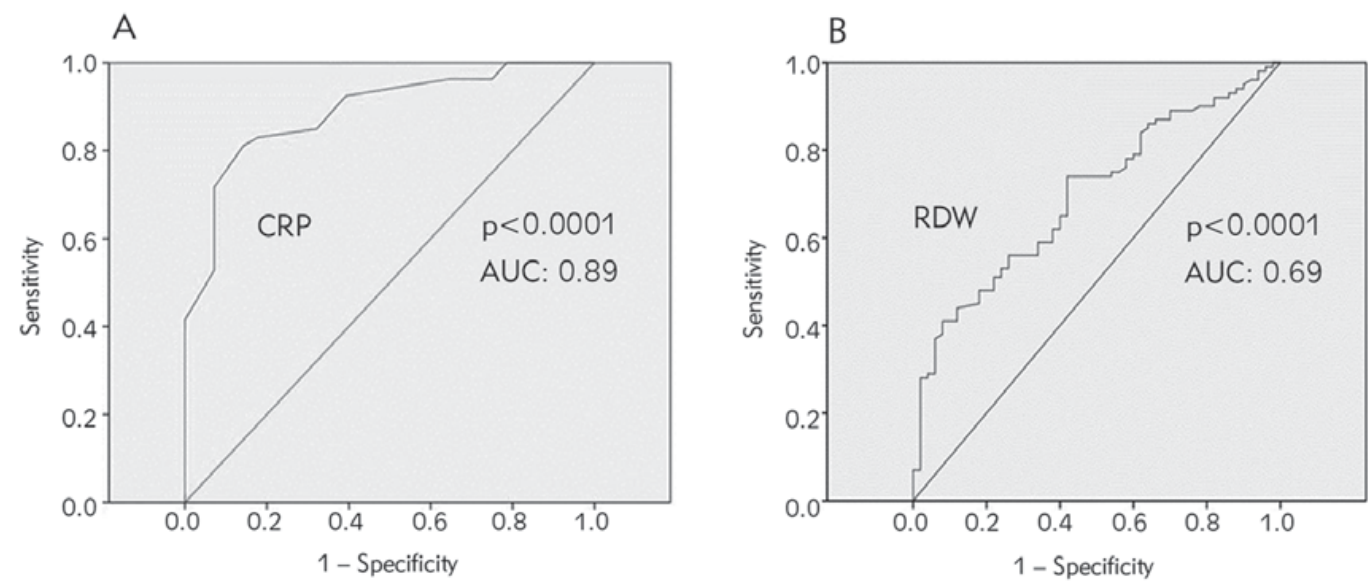

Figure 2 A) ROC curve for using CRP (C-reactive protein) levels and AUC value (area under the curve) in the differential diagnosis of Group 1 (COPD patients with stable) and Group 2 (COPD patients with exacerbation). B) ROC curve for using RDW (red cell distribution width) levels and AUC value in the differential diagnosis of Group 1 and Group 2.

\section{Discussion}

COPD is considered a systemic disease that is associated with independent risk factors such as diabetes, hypertension, and cardiovascular diseases that have tended to increase in recent years (14). Since the early 2000s, several studies associating COPD with systemic extra pulmonary diseases (i.e., systemic inflammation and comorbidities) had been published (3, 15-17). The proposed mechanism of such comorbidities in COPD includes hypoxia, oxidative stress, and systemic inflammation (18), and so it can be expected that systemic inflammatory markers will increase in COPD patients when compared to healthy individuals. There have been several studies showing that inflammatory markers such as CRP, fibrinogen, IL-6, IL-8, and TNF- $\alpha$ increase in patients with COPD and even in patients with stable COPD when compared to healthy individuals, and that the increased levels of these markers are associated with acute exacerbation and mortality $(2,4,15)$.

Serum leukocyte count is another marker of inflammation. As a compensatory mechanism for the control of infective presentation, certain cytokines such as IL-8 released by macrophages, which are the first-line defense mechanism against infections, stimulate hematopoiesis, thereby increasing serum leukocyte counts (19). Given the correlation between the severity of infection and leukocyte count, previous studies have stated that an elevated serum leukocyte 
count is directly associated with the increased frequency and severity of exacerbations in COPD patients $(20,21)$, and in addition, increased leukocyte and neutrophil counts are significantly associated with mortality (22). Similarly, in the present study, increased leukocyte and neutrophil counts were noted in the hospitalized patients with acute exacerbation of COPD when compared to stable patients.

CRP is one of the most commonly used inflammatory markers in clinical practice. Previous studies have identified higher serum CRP values in stable COPD patients than in healthy individuals (23, 24). In severe COPD patients, CRP values have also been found to be elevated, more than in mild-tomoderate patients $(24,25)$. Consistent with literature, we observed in the present study that CRP values were higher in patients with acute exacerbation of COPD than in the stable patients or healthy controls and higher also in the stable patients than in the healthy controls.

Although the effect of lymphocytopenia on chronic inflammatory diseases is not precisely known, it has been associated with poor prognosis in acute inflammatory diseases such as sepsis or bacteremia (26). In addition, lymphocytopenia has been associated with all-cause mortality in COPD patients $(27,28)$. In the present study, we also identified a lower lymphocyte count in patients with acute exacerbation of COPD than in the stable patients or the healthy controls and lower also in the stable patients than in the healthy controls.

Platelets modulate inflammatory response. Thrombocytosis is used as a marker of acute phase reaction and in recent years, thrombocytosis has also been considered a prognostic marker for H1N1 influenza, community-acquired pneumonia, disseminated intravascular coagulation, sepsis, vitamin deficiencies, drug-induced toxicity and several pathophysiological disorders (29-31). Although there are only a limited number of studies on platelet counts in COPD patients, thrombocytopenia has been reported in COPD patients with acute exacerbation and has been associated with poor prognosis and increased mortality (32). Consistent with these findings, we also found lower platelet counts in the COPD patients with acute exacerbation than in the stable patients.

$M P V$, as an indicator of platelet activation, is another inflammatory marker. PCT is accepted as an indicator of circulating platelets in one unit volume of blood. In a previous study, MPV was shown to reduce during acute exacerbation of COPD (33). In several studies conducted in Turkey, MPV decreased significantly in patients with acute exacerbation of COPD when compared to stable patients $(27,34)$. In the present study, we also found that both MPV and PCT decreased significantly in the patients with acute exacerbation of COPD when compared to table patients.
It has been demonstrated that NLR is superior to neutrophil count alone, as an inflammatory marker, and to lymphocytopenia alone, which indicates impaired immunity and a deteriorated health condition, for the evaluation of the severity of COPD (12). NLR is a simple and cost-effective marker that does not require additional laboratory workup (35) that in recent years has been widely used in several conditions in clinical practice. In a study, NLR was identified as a highly-sensitive marker predicting and identifying mortality in patients with communityacquired pneumonia (36). In another study, NLR was found to be superior to CRP and neutrophil and to leukocyte counts alone, in identifying bacteremia in an emergency setting (37). Similarly, NLR was seen to increase in patients with advanced lung cancer and was found useful for the evaluation of disease severity and prognosis (38). In another prospective study staged in Korea, NLR was significantly higher in patients with acute exacerbation of COPD than in stable patients and a cut-off value of $>2.8$ was shown to be a useful marker when predicting COPD-related hospitalization (11). In another Korean study, as NLR increased, airway narrowing increased, highlighting NLR as a prognostic marker in predicting further COPD exacerbations (12). In a study carried out in Turkey, NLR was found to have a high prognostic value, similar to CRP, for acute exacerbations of COPD, and demonstrated higher sensitivity and specificity than PLR (35). Karadeniz et al. (34) reported higher PLR values in patients with acute exacerbation of COPD than in stable patients, suggesting that higher PLR was associated with low FEV1. In a study carried out in Turkey, a NLR value of $>4.50$ was found to be associated with an increased risk for readmission due to exacerbation within a month in patients with acute exacerbation of COPD, and the authors concluded that increased NLR values might be useful in predicting further exacerbations in COPD patients (39). In the present study, we also found statistically significantly higher NLR and PLR values in patients with acute exacerbation of COPD than in stable patients and healthy controls. In addition, a NLR cut-off of $>2.84$ was noted in patients hospitalized due to acute exacerbation of COPD with a higher sensitivity and specificity than PLR.

The results of studies on serum eosinophil count in the event of an acute exacerbation were different. In one study, eosinophilia was reported also in patients with stable COPD as well as in the event of an acute exacerbation (40). Another study identified a significant relationship between eosinopenia and duration of hospitalization, the need for mechanical ventilation, hospital death, re-hospitalization and mortality within 30 days after discharge in COPD patients with acute exacerbation (41). In the present study, it was observed that the serum eosinophil count did not change in COPD patients with acute exacerbation. 
In one study, an increased RDW was found to be compatible with previous studies reporting a correlation between RDW and stable COPD severity (42). In another study increased RDW was reported as an independent negative prognostic factor associated with adverse outcomes after hospitalization due to acute exacerbation of COPD (43). We also found higher RDW levels in COPD patients with acute exacerbation than in stable patients in the present study.

No studies were found in literature reporting these markers (especially NLR and PLR) in COPD patients with bronchiectasis, although a limited number of studies reporting on bronchiectasis alone were found involving adult and child patients. In one such study, it was reported that CRP (not NLR) was the best marker in a new scoring system measuring the severity of systemic inflammation in patients with stable bronchiectasis (44). In a study of child patients with bronchiectasis, it was concluded that leukocyte count, platelet count, absolute neutrophil count, and NLR could be used to show chronic inflammation in bronchiectasis, but that only NLR and absolute neutrophil count could be used as biomarkers to show acute exacerbations (45). In the present study, NLR and PLR values were higher only in stable COPD patients with bronchiectasis than those without bronchiectasis.

There were some limitations to the present study. Firstly, the study was both retrospective and prospective. PFT (pulmonary function test) was

\section{References}

1. Global Initiative for Chronic Obstructive Lung Disease (GOLD). Global strategy for the diagnosis, management, and prevention of chronic obstructive pulmonary disease: 2018 Report. http: //goldcopd.org/wp-content/ uploads/2017/11/GOLD-2018-v6.0-FINAL-revised-20Nov_WMS.pdf.

2. Thomsen M, Dahl M, Lange P, Vestbo J, Nordestgaard BG. Inflammatory biomarkers and comorbidities in chronic obstructive pulmonary disease. Am J Respir Crit Care Med 2012; 186: 982-8.

3. Avci E, Avci AG: Important biomarkers that play a role in the chronic obstructive pulmonary disease process. J Med Biochem 2018; 37: 46-53.

4. Agusti A, Edwards LD, Rennard SI, MacNee W, TalSinger R, Miller BE, et al. Persistent systemic inflammation is associated with poor clinical outcomes in COPD: A novel phenotype. PLoS One 2012; 7(5): e37483.

5. Telo S, Kuluöztürk M, Deveci F, Kırkıl G, Öner Ö, Kaman $D$. Serum cystatin c levels in copd: potential diagnostic value and relation between respiratory functions. J Med Biochem 2018; 37: 434-40. performed in all prospective patients, while the PFT values of some retrospective patients (especially those with acute exacerbation) were unavailable. Accordingly PFT severity assessment could not be performed. Secondly, the study was carried out at a single center.

\section{Conclusion}

In addition to leukocyte and CRP; NLR, PLR and RDW values were found to be significantly increased as markers in COPD patients with acute exacerbation. Our study results suggest that NLR, PLR and RDW are thought to be important, costeffective, inexpensive and easily measurable parameters, and to be useful in predicting the severity of COPD exacerbation, hospitalization, and future exacerbation.

\section{Author Contributions}

F.S. formulated the hypothesis, performed data entry and data analysis, and wrote and reviewed the manuscript; A.F.K. participated data entry; A.F.A. participated data entry and analysis; B.Y. participated data entry; B.U. participated data entry. All authors read and approved the final manuscript.

\section{Conflict of interest statement}

The authors stated that they have no conflicts of interest regarding the publication of this article.

6. Vestbo J. Clinical assessment, staging, and epidemiology of chronic obstructive pulmonary disease exacerbations. Proc Am Thorac Soc 2006; 3: 252-6.

7. Ceylan C, Camtosun A, Doluoglu OG, Tasdemir S, Keles I, Aglamis E, et al. Emphasis of neutrophil-to-lymphocyte ratio in non-metastatic renal cell carcinoma. Urologia 2014; 81(1): 51-6.

8. Tamhane UU, Aneja S, Montgomery D, Rogers EK, Eagle KA, Gurm HS. Association between admission neutrophil to lymphocyte ratio and outcomes in patients with acute coronary syndrome. Am J Cardiol 2008; 102: 653-7.

9. Kemal Y, Yucel I, Ekiz K, Demirag G, Yilmaz B, Teker F, et al. Elevated serum neutrophil to lymphocyte and platelet to lymphocyte ratios could be useful in lung cancer diagnosis. Asian Pac J Cancer Prev 2014; 15(6): 2651-4.

10. Kayrak M, Erdo an HI, Solak Y, Akilli H, Gül EE, Yildirim $O$, et al. Prognostic value of neutrophil to lymphocyte ratio in patients with acute pulmonary embolism: a restrospective study. Heart Lung Circ 2014; 23: 56-62. 
11. Lee SJ, Lee HR, Lee TW, Ju S, Lim S, Go SI, et al. Usefulness of neutrophil to lymphocyte ratio in patients with chronic obstructive pulmonary disease: a prospective observational study. Korean J Intern Med. 2016 Sep; 31(5): 891-8.

12. Lee H, Um SJ, Kim YS, Kim DK, Jang AS, Choi HS, et al. Association of the Neutrophil-to-Lymphocyte Ratio with Lung Function and Exacerbations in Patients with Chronic Obstructive Pulmonary Disease. PLoS One. 2016 Jun 3; 11(6): e0156511.

13. American Thoracic Society, European Respiratory Society Task Force. Standards for the Diagnosis and Management of Patients with COPD. Version 1.2. New York, NY: American Thoracic Society; 2004. http: //www.thoracic. org/go/copd.

14. Vanfleteren LE, Spruit MA, Groenen M, Gaffron S, van Empel VP, Bruijnzeel PL, et al. Clusters of comorbidities based on validated objective measurements and systemic inflammation in patients with chronic obstructive pulmonary disease. Am J Respir Crit Care Med 2013; 187: $728-35$.

15. Walter RE, Wilk JB, Larson MG, Vasan RS, Keaney JF Jr, Lipinska I, et al. Systemic inflammation and COPD: the Framingham Heart Study. Chest 2008; 133: 19-25. PMID: 17908709

16. Agustí AG, Noguera A, Sauleda J, Sala E, Pons J, Busquets $X$. Systemic effects of chronic obstructive pulmonary disease. Eur Respir J 2003; 21: 347-60.

17. MacNee W. Systemic inflammatory biomarkers and comorbidities of chronic obstructive pulmonary disease. Ann Med 2013; 45: 291-300.

18. Mills NL, Miller JJ, Anand A, Robinson SD, Frazer GA, Anderson D, et al. Increased arterial stiffness in patients with chronic obstructive pulmonary disease: a mechanism for increased cardiovascular risk. Thorax 2008; 63: 306-11.

19. Bienvenu J. Exploration of cytokines in biological fluids. CR Seances Soc Biol Fil 1995; 189: 545-55.

20. Hurst JR, Vestbo J, Anzueto A, Locantore N, Müllerova $\mathrm{H}$, Tal-Singer $\mathrm{R}$, et al. Susceptibility to exacerbation in chronic obstructive pulmonary disease. N Engl J Med 2010; 363: 1128-38.

21. Thomsen $M$, Ingebrigtsen TS, Marott JL, Dahl M, Lange $P$, Vestbo J, et al. Inflammatory biomarkers and exacerbations in chronic obstructive pulmonary disease. JAMA 2013; 309: 2353-61.

22. Celli BR, Locantore N, Yates J, Tal-Singer R, Miller BE, Bakke $\mathrm{P}$, et al. Inflammatory biomarkers improve clinical prediction of mortality in chronic obstructive pulmonary disease. Am J Respir Crit Care Med 2012; 185: 106572 .

23. Firouzjahi A, Monadi $M$, Karimpoor $F$, Heidari $B$, Dankoob Y, Hajian-Tilaki K, et al. Serum C-reactive protein level and distribution in chronic obstructive pulmonary disease versus healthy controls: a casecontrol study from Iran. Inflammation 2013; 36: 11228.

24. Zhang $Y$, Bunjhoo $H$, Xiong $W, X u Y$, Yang D. Association between $\mathrm{C}$-reactive protein concentration and chronic obstructive pulmonary disease: a systematic review and meta-analysis. J Int Med Res 2012; 40: 1629-35.

25. El-Deek SE, Makhlouf HA, Saleem TH, Mandour MA, Mohamed NA. Surfactant protein D, soluble intercellular adhesion molecule-1 and high-sensitivity C-reactive protein as biomarkers of chronic obstructive pulmonary disease. Med Princ Pract 2013; 22: 469-74.

26. Drewry AM, Samra N, Skrupky LP, Fuller BM, Compton SM, Hotchkiss RS. Persistent lymphopenia after diagnosis of sepsis predicts mortality. Shock 2015; 42: 383-91.

27. Günay E, Sarınç Ula lı S, Akar O, Ahsen A, Günay S, Koyuncu $T$, et al. Neutrophil-to-lymphocyte ratio in chronic obstructive pulmonary disease: a retrospective study. Inflammation 2014; 37: 374-80.

28. Sørensen AK, Holmgaard DB, Mygind LH, Johansen J, Pedersen C. Neutrophil-to-lymphocyteratio, calprotectin and YKL-40 in patients with chronic obstructive pulmonary disease: correlations and 5 year mortality-a cohort study. J Inflamm 2015; 12: 20.

29. Lopez-Delgado JC, Rovira A, Esteve F, Rico N, Mañez Mendiluce R, Ballús Noguera J, et al. Thrombocytopenia as a mortality risk factor in acute respiratory failure in H1N1 influenza. Swiss Medical Weekly 2013; 18: w13788.

30. Brogly N, Devos P, Boussekey N, Georges H, Chiche A, Leroy O. Impact of thrombocytopenia on outcome of patients admitted to ICU for severe community-acquired pneumonia. J Infect 2007; 55: 136-40.

31. Moreau D, Timsit JF, Vesin A, Garrouste-Orgeas M, de Lassence A, Zahar JR, et al. Platelet count decline: an early prognostic marker in critically ill patients with prolonged ICU stays. Chest 2007; 131: 1735-41.

32. Rahimi-Rad MH, Soltani S, Rabieepour M, Rahimirad S. Thrombocytopenia as a marker of outcome in patients with acute exacerbation of chronic obstructive pulmonary disease. Pneumonol Alergol Pol 2015; 83(5): 348-51.

33. Wang RT, Li JY, Cao ZG, Li Y. Mean platelet volume is decreased during an acute exacerbation of chronic obstructive pulmonary disease. Respirology 2013; 18 : 12448.

34. Karadeniz G, Akto u S, Erer OF, Kır SB, Doruk S, Demir $M$, et al. Predictive value of platelet-to-lymphocyte ratio in exacerbation of chronic obstructive pulmonary disease. Biomarkers in Medicine, July 2016, 10(7): 701-10.

35. Kurtipek E, Bekci TT, Kesli R, Sami SS, Terzi Y. The role of neutrophil-lymphocyte ratio and platelet-lymphocyte ratio in exacerbation of chronic obstructive pulmonary disease J Pak Med Assoc 2015 Dec; 65(12): 1283-7.

36. de Jager $C P$, Wever PC, Gemen EF, Kusters R, van Gageldonk-Lafeber AB, van der Poll T, et al. The Neutrophil-Lymphocyte Count Ratio in Patients with Community-Acquired Pneumonia. PLoS One 2012; 7 : e46561.

37. de Jager CP, van Wijk PT, Mathoera RB, de JonghLeuvenink J, van der Poll T, Wever PC. Lymphocytopenia and neutrophil lymphocyte count ratio predict bacteremia better than conventional infection markers in an emergency care unit. Crit Care 2010; 14: R192. 
38. Unal D, Eroglu C, Kurtul N, Oguz A, Tasdemir A. Are neutrophil/lymphocyte and platelet/lymphocyte rates in patients with non-small cell lung cancer associated with treatment response and prognosis? Asian Pac J Cancer Prev 2013: 14; 5237-42.

39. Çoban Ağca M, Aksoy E, Duman D, Özmen İ, Yıldırım E, Güngör $S$, et al. Does eosinophilia and neutrophil to lymphocyte ratio affect hospital re-admission in cases of copd exacerbation? Tuberk Toraks 2017 Dec; 65(4): 282-90.

40. Kitaguchi $Y$, Komatsu Y, Fujimoto K, Hanaoka M, Kubo K. Sputum eosinophilia can predict responsiveness to inhaled corticosteroid treatment in patients with overlap syndrome of COPD and asthma. Int J Chron Obstruct Pulmon Dis 2012; 7: 283-9.

41. Rahimi-Rad MH, Asgari B, Hosseinzadeh N, Eishi A. Eosinopenia as a Marker of Outcome in Acute Exacerbations of Chronic Obstructive Pulmonary Disease. Maedica (Buchar). 2015 Mar; 10(1): 10-3.
42. Kalemci S, Akin F, Sarihan A, Sahin C, Zeybek A, Yilmaz $\mathrm{N}$. The relationship between hematological parameters and the severity level of chronic obstructive lung disease. Pol Arch Intern Med 2018 Jan 31; 128(3): 171-7.

43. Epstein D, Nasser R, Mashiach T, Azzam ZS, Berger G. Increased red cell distribution width: A novel predictor of adverse outcome in patients hospitalized due to acute exacerbation of chronic obstructive pulmonary disease. Respir Med 2018 Mar; 136: 1-7.

44. Coban H, Gungen AC. Is There a Correlation between New Scoring Systems and Systemic Inflammation in Stable Bronchiectasis? Can Respir J 2017; 2017: 9874068.

45. Nacaroglu HT, Erdem SB, Karaman S, Yazici S, Can D. Can mean platelet volume and neutrophil-to-lymphocyte ratio be biomarkers of acute exacerbation of bronchiectasis in children? Cent Eur J Immunol 2017; 42(4): 358-62. 